\title{
PHENOTYPIC VARIABILITY OF FERTILITY TRAITS OF PURE BREED SOWS IN FIRST THREE FARROWINGS**
}

\author{
D. Radojković ${ }^{1 *}$, M. Petrović ${ }^{1}$, M. Mijatović ${ }^{1}, \check{C}^{\text {. }}$ Radović $^{2}$ \\ ${ }^{1}$ University Of Belgrade, Faculty Of Agriculture, Institute for zootechnica, Belgrade-Zemun \\ ${ }^{2}$ Institute For Animal Husbandry, Belgrade-Zemun \\ Corresponding author: \\ *Dragan Radojković, e-mail: radodrag@agrifaculty.bg.ac.yu \\ **Original scientific paper (originalni naucni rad)
}

\begin{abstract}
Investigation of the phenotypic variability of fertility traits was performed on Swedish Landrace sows (926 sows) deriving from single herd in Serbia. Data was processed by method of least squares (Harvey, 1990), and following fixed factors were included into the model: sire, season, litter genotype and order of farrowing, as well as regression effect of age at first farrowing, duration of lactation and number of reared (raised) piglets per litter.

Traits of litter size varied $(\mathrm{P}<0.01)$ under the influence of sire and order of parities (first two parities). Number of still born as well as reared piglets per litter depended on the litter genotype $(\mathrm{P}<0.01)$. Year and season had no effect on variation of litter size traits except LWW (first two and three parities). Age of sows at first farrowing demonstrated linear effect $(\mathrm{P}<0.01)$ on size of their litter at farrowing (first three parities). Litter size and weight at weaning were under regression effect of lactation duration as well as corrected litter size (CLS) or number of weaned piglets (NW).
\end{abstract}

Key words: sows, Swedish Landrace, fertility, variability

\section{Introduction}

Improving of fertility traits of pigs is in the centre of attention of breeders as well as researchers engaged in the field of pig production. Breeders are mainly occupied with this problem since economical efficiency of pig production cycle and pork production is directly depending on the success in reproduction, and researchers because of present limitations in regard to the improvement of this group of traits through selection. However, 
in spite of actual problems concerning this issue and according to modern knowledge, serious and consistent selection work is single reliable method and means for achieving higher fertility of pigs (Radojković and Petrović Milica, 2002). This refers especially to improvement of fertility of pigs during a longer period of time and in larger populations (for instance on national or regional level).

Fertility of pigs varies under the influence of different parameters of genetic and paragenetic nature. Of great importance is as accurate as possible determination of environmental factors that can influence the achieved fertility of pigs (Petrović Milica et al., 1998a). This is of greatest importance in case of determination of genetic parameters, in order to make correction of phenotypic values of fertility traits in relation to the effect of known factors and increase their accuracy, by using adequate mathematicalstatistical procedures.

Objective of this paper was to determine phenotypic variability of fertility traits in single population of Swedish Landrace sows in Serbia. Variability was investigated based on realized sow fertility in the first parity, the first two parities and first three parities.

\section{Material and method}

Phenotypic variability of fertility traits was determined in swedish landrace sows on one farm in Serbia. Research included 926 sows and 926 of their first parities, 1598 of the first two parities and 2115 of first three parities. Sows originated from 43 sires.

Data was processed by method of Least squares - programme package LSMLMW and MIXMDL (Harvey, 1990)

Following fixed model of least squares method was used in order to determine the phenotypic variability of the period from weaning to oestrus (W-E), from weaning to conception (W-C) and litter weight at weaning (LWW):

$\mathrm{Y}_{\mathrm{ijklm}}=\mu+\mathrm{S}_{\mathrm{i}}+\mathrm{Ye}_{\mathrm{j}}+\mathrm{Se}_{\mathrm{k}}+\mathrm{G}_{1}+\mathrm{b}_{1}\left(\mathrm{X}_{1}-\overline{\mathrm{X}}_{1}\right)+\mathrm{b}_{2}\left(\mathrm{X}_{2}-\overline{\mathrm{X}}_{2}\right)+\mathrm{b}_{3}\left(\mathrm{X}_{3}-\overline{\mathrm{X}}_{3}\right)+\mathrm{e}_{\mathrm{ijklm}}$

where:

$\mathrm{Y}_{\mathrm{IJKLM}}$ - expression of the trait in m-individual animal, originating from $\mathrm{i}$-sire, at j-year, k-season, l- litter genotype,

$\mu$-general average, 
$\mathrm{S}_{\mathrm{i}}$ - fixed influence of $\mathrm{i}$-sire $(\mathrm{i}=1, \ldots, 43)$,

$\mathrm{Ye}_{\mathrm{j}}$ - fixed influence of $\mathrm{j}$-year $(\mathrm{j}=1, \ldots, 6)$,

$\mathrm{Se}_{\mathrm{k}}$ - fixed influence of $\mathrm{k}$-season $(\mathrm{k}=1, \ldots, 4)$,

$\mathrm{G}_{1}$ - fixed influence of 1-litter genotype, pure breed and crossbreds $(l=1,2)$ (except in case of W-E and W-C),

$\mathrm{b}_{1}\left(\mathrm{X}_{1}-\overline{\mathrm{X}}_{1}\right)$ - linear regression influence of gilt's age at first farrowing (AFF),

$\mathrm{b}_{2}\left(\mathrm{X}_{2}-\overline{\mathrm{X}}_{2}\right)$ - linear regression influence of lactation duration (L),

$\mathrm{b}_{3}\left(\mathrm{X}_{3}-\overline{\mathrm{X}}_{3}\right)$ linear regression influence of litter size at weaning $(\mathrm{NW})$ and

$\mathrm{e}_{\mathrm{ijklm}}-$ random error.

For determination of phenotypic variability of litter size traits at farrowing (NBA, TNB and NSB), regression influences of lactation duration $\left(b_{2}\right)$ and litter size at weaning $\left(b_{3}\right)$ were excluded from the presented fixed model of the least squares method.

For investigation of phenotypic variability of litter size at weaning (NW) initial step was presented fixed model of the least squares method, however, instead of regression influence of litter size at weaning linear regression influence of litter size raised by the sow (subsequent to correction of the litter size at birth or subtraction of piglets - equalization of litter, CLS) was included.

For determination of phenotypic variability of investigated traits in first two parities, and first three parities, fixed influence of the order of parity (P) was included into described model of the least squares method.

\section{Results and discussion}

In Table 1, average expression of investigated fertility traits of sows is presented as general average in application of adequate models of the least squares method.

From presented results it can be concluded that periods from weaning to first oestrus and conception were the longest after first parity, getting shorter in subsequent cycles. This is in accordance with results obtained by Teodorovic et al. (1995), Kosovac Olga et al. (1994) and Petrovic Milica et al. (1998a). Established values of investigated parameters were within the limits determined by above mentioned authors. 
Table 1. Average expression of fertility traits of sows in first parity, first two and first three parities.

Tabela 1. Prosečna ispoljenost osobina plodnosti krmača u prvom, prva dva i prva tri prašenja

\begin{tabular}{cccc}
\hline $\begin{array}{c}\text { Trait }^{2} \\
\text { (Osobina) }\end{array}$ & $\begin{array}{c}\mathbf{I}^{\mathbf{1}} \\
\boldsymbol{\mu} \pm \text { S.E. }\end{array}$ & $\begin{array}{c}\mathbf{I}+\mathbf{I I} \\
\boldsymbol{\mu} \pm \text { S.E. }\end{array}$ & $\begin{array}{c}\text { I + II + III } \\
\boldsymbol{\mu} \pm \text { S.E. }\end{array}$ \\
\hline \hline W-E & $9.77 \pm 0.86$ & $8.51 \pm 0.81$ & $7.80 \pm 0.70$ \\
W-C & $23.77 \pm 2.13$ & $20.98 \pm 1.81$ & $19.49 \pm 1.68$ \\
NBA & $8.31 \pm 0.10$ & $8.91 \pm 0.08$ & $9.19 \pm 0.07$ \\
TNB & $8.87 \pm 0.10$ & $9.46 \pm 0.08$ & $9.78 \pm 0.07$ \\
NSB & $0.56 \pm 0.04$ & $0.54 \pm 0.03$ & $0.51 \pm 0.03$ \\
NW & $7.57 \pm 0.07$ & $8.04 \pm 0.05$ & $8.24 \pm 0.04$ \\
LWW & $52.43 \pm 0.33$ & $58.18 \pm 0.29$ & $61.10 \pm 0.29$ \\
\hline
\end{tabular}

${ }^{1}$ I - first parity (prvo prašenje); I + II - first two parities (prva dva prašenja); I + II + III - first three parities (prva tri prašenja).

${ }^{2} \mathrm{~W}-\mathrm{E}$ : weaning to oestrus period (period zalučenje-estrus); W-C: weaning to conception period (period zalučenje-oplodnja); NBA: number of born alive piglets (broj živorođene prasadi); TNB: total number of born piglets (broj ukupnorođene prasadi); NSB: number of stillborn piglets (broj mrtvotođene prasadi); NW: number of weaned piglets (broj odgajene prasadi); LWW: litter weight on weaning (masa legla pri zalučenju).

In regard to the traits of litter size and weight (except NSB) contrary tendency can be observed. Values of mentioned traits increased in first three parities, also established in numerous investigations by different authors (Roehe and Kennedy, 1995, Teodorović et al., 1995, Beličovski et al., 1997, Petrović Milica et al., 1998a). Determined litter sizes at birth and weaning can not be evaluated as satisfactory since genetic potential of breed Swedish Landrace is considerably higher confirmed by results of mentioned investigations (except investigation by Beličovski et al., 1997).

There are contradictory opinions in regard to the potential influence of boar on size of his direct litters (Table 2). Contrary to this, effect of boar on litter size of his daughters was confirmed in numerous investigations. Statistically highly significant $(\mathrm{P}<0.01)$ differences between groups of halfsisters with same sire were determined for all fertility traits except duration of period from weaning to first oestrus and conception (W-E and W-C). These traits were statistically significant only for litter size at birth in first parity (NBA and TNB), but they were not confirmed for number of still born piglets in same parity. Effect of sires on litter size of his daughters in consecutive parities was also determined in investigation of Petrović Milica et al. (1998a) and Petrović Milica et al. (1998b), whereas Kosovac Olga and 
Petrović Milica (1995) did not establish this effect in first farrowing sows contrary to other parities.

Effect of years on variation of fertility traits wasn't observed except for the period from weaning to first oestrus and conception, number of still born piglets (in first three parities) and litter weight at weaning (in first two and first three parities). Absence of relation between traits of litter size and influence of year was determined and this is in accordance with investigations presented by Estany and Sorensen (1995) and Beličovski et al. (1997), and contrary to results obtained by another group of authors (Teodorović et al., 1995, Petrović Milica et al., 1998a, Petrović Milica et al., 1998b, Kim et., 1998, Tölle et al., 1998 and Teodorović et., 1999).

Seasons had no effect on variation of fertility traits except on litter weight at weaning in first two and first three parities (LWW). Obtained results relating to this factor are in accordance with investigation results presented by Shostak and Benkov (1992), also Teodorović et al. (1999), and contrary to investigation results obtained by Estany and Sorensen (1995), Petrović Milica et al. (1998a) and Petrović Milica et al. (1998b).

Litter genotype, that is, whether boars of same or different breeds were used for conception of females included into this investigation, influenced number of still born and number of weaned piglets in litter. When boars of other breeds are used, it is possible to obtain heterosis effect in offspring in regard to their constitution traits (resistance) and vitality (vital abilities), which can affect the success of embrio implantation as well as the level of prenatal, perinatal and postnatal losses. Effect of this parameter on mentioned traits was presented by Zebrowski et al. (1991) and Tölle et al. (1998), which is contrary to the investigations by Hoang and Sivarajasingam (1998).

Effect of order of farrowing on achieved fertility of sows was statistically highly significant $(\mathrm{P}<0.01)$. Only in case of period from weaning to first oestrus and conception in first two parities and number of still born piglets in first three parities this effect was rated as statistically significant $(\mathrm{P}<0.05)$. Significant variation of fertility traits in different order of parities was determined by numerous authors (Teodorović et al., 1995, Petrović Milica et al., 1998a, Petrović Milica et al., 1998b and Boesch et al., 1998). Contrary to previous investigations presented by Beličovski et al. (1997) effect of order of farrowing on litter size at birth was not established, contrary to the effect on litter size and weight at weaning.

Age at first farrowing expressed linear influence $(\mathrm{P}<0.01)$ only on litter size at birth (NBA and TNB) which is also in accordance with results 
obtained by Teodorović et al. (1995), Petrović Milica et al. (1998a), Petrović Milica et al. (1998b) and Teodorović et al. (1999). Effect of this parameter on litter size at birth wasn't established by Kosovac Olga and Petrović Milica (1995).

Table 2. Effect of genetic and environmental factors on fertility traits of sows in first three parities

Tabela 2. Uticaj genetskih i faktora okoline na osobine plodnosti krmača u prva tri prašenja

\begin{tabular}{|c|c|c|c|c|c|c|c|c|c|}
\hline \multirow{2}{*}{$\begin{array}{c}\text { Trait } \\
\text { (Osobina) }\end{array}$} & \multirow{2}{*}{$\begin{array}{c}\text { Parity } \\
\text { (Prašenje) }\end{array}$} & \multicolumn{8}{|c|}{ Factor (Faktor) } \\
\hline & & $\mathrm{S}^{1}$ & $\mathbf{Y}$ & Se & $\mathbf{G}$ & $\mathbf{P}$ & AFF & $\mathbf{L}$ & CLS \\
\hline \multirow{3}{*}{$\mathbf{W}-\mathbf{E}^{2}$} & $\begin{array}{l}I^{3} \\
\end{array}$ & $\overline{\mathrm{ns}^{4}}$ & *** & 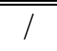 & 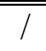 & 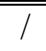 & $1 /$ & $1 /$ & $1 /$ \\
\hline & $\mathbf{I}+\mathbf{I I}$ & ns & / & / & / & $*$ & / & l & / \\
\hline & I+II+III & ns & 1 & l & 1 & $* *$ & 1 & 1 & $* *$ \\
\hline \multirow{3}{*}{ W-C } & $\mathbf{I}^{3}$ & ns & 1 & / & / & 1 & 1 & 1 & 1 \\
\hline & I+II & ns & $*$ & / & / & $* *$ & / & / & / \\
\hline & I+II+III & ns & $* *$ & l & l & $* *$ & / & l & l \\
\hline \multirow{3}{*}{ NBA } & $\mathbf{I}^{3}$ & $*$ & 1 & 1 & 1 & 1 & $* *$ & 1 & 1 \\
\hline & $\mathbf{I}+\mathbf{I I}$ & $* *$ & / & / & / & $* *$ & $* *$ & / & / \\
\hline & I+II+III & $* *$ & / & / & / & $* *$ & $* *$ & / & / \\
\hline \multirow{3}{*}{ TNB } & $\mathbf{I}^{3}$ & $*$ & 1 & 1 & 1 & 1 & $* *$ & 1 & 1 \\
\hline & I+II & $* *$ & / & I & / & $* *$ & $* *$ & / & / \\
\hline & I+II+III & $* *$ & l & 1 & 1 & $* *$ & $* *$ & I & 1 \\
\hline \multirow{3}{*}{ NSB } & $\mathbf{I}^{3}$ & ns & 1 & / & 1 & 1 & / & 1 & / \\
\hline & I+II & $* *$ & l & / & $* *$ & l & l & l & l \\
\hline & I+II +III & $* *$ & $*$ & I & $* *$ & $*$ & / & / & / \\
\hline \multirow{3}{*}{ NW } & $\mathbf{I}^{3}$ & $* *$ & 1 & 1 & $* *$ & 1 & 1 & 1 & $* *$ \\
\hline & I+II & $* *$ & / & / & $* *$ & $* *$ & / & $* *$ & $* *$ \\
\hline & I+II+III & $* *$ & / & / & $* *$ & $* *$ & / & $* *$ & $* *$ \\
\hline \multirow{3}{*}{ LWW } & $\mathbf{I}^{3}$ & $* *$ & 1 & 1 & 1 & 1 & 1 & $* *$ & $* *$ \\
\hline & I+II & $* *$ & $* *$ & $* *$ & / & $* *$ & l & $* *$ & $* *$ \\
\hline & I+II+III & $* *$ & $* *$ & $* *$ & 1 & $* *$ & I & $* *$ & $* *$ \\
\hline
\end{tabular}

${ }^{1} \mathrm{~S}$ - sire (otac); Y - year (godina); Se - season (sezona); G - genotype of litter (genotip legla); $\mathrm{P}$ - parity (prašenje); AFF - age at first farrowing (uzrast pri prvom prašenju); L - duration of lactation (trajanje laktacije); CLS - corrected litter size (korigovana veličina legla).

${ }^{2} \mathrm{~W}-\mathrm{E}$ : weaning to oestrus period (period zalučenje-estrus); W-C: weaning to conception period (period zalučenje-oplodnja); NBA: number of born alive piglets (broj živorođene prasadi); TNB: total number of born piglets (broj ukupnorođene prasadi); NSB: number of stillborn piglets (broj mrtvorođene prasadi); NW: number of weaned piglets (broj odgajene prasadi); LWW: litter weight on weaning (masa legla pri zalučenju).

${ }^{3}$ I - first parity (prvo prašenje); I + II - first two parities (prva dva prašenja); I + II + III - first three parities (prva tri prašenja).

${ }^{4} \mathrm{NS}-\mathrm{p}>0.05 ; *-\mathrm{p}<0.05 ; * *-\mathrm{p}<0.01$. 
Duration of lactation expressed linear regression influence $(\mathrm{P}<0.01)$ on litter size and weight at weaning (NW and LWW). This was expected especially in regard to the influence of this parameter on LWW. Correlation between number of weaned piglets and duration of lactation is determined which is in accordance with investigation presented by Petrović Milica et al. (1998b).

Number of weaned piglets was under direct linear influence of number of piglets in litter raised by sow (CLS). Determined middle of the rectangle during the analysis of variance indicates that this trait varied dominantly under the influence of this factor. Since in production conditions, and as obligatory measure in terms of breeding technology, equalisation of litter is carried out, it is necessary to take into consideration number of added or subtracted piglets from the litter farrowed by the sow when determining the variability of this trait. Also, when investigating variability of LWW, the influence of number of weaned piglets must also be taken into account. In this investigation this parameter expressed direct linear influence on mentioned trait and greatly contributed to the variation of the expression of this trait. This must be taken into consideration when determining genetic parameters. If not, unrealistic evaluations of mentioned parameters could be obtained since effects referred to could accidentally be attributed to the effect of genetic groups of sires and dams, depending on the variance components based on which genetic components are calculated. If, for any reason, it is not possible to include such factors in corresponding models of linear methods in analysing variability of fertility traits, then it is necessary to carry out correction of traits on average or previously determined values (for instance standard duration of lactation from 21 to 28 days) of these factors. Investigation by Yen et al. (1987), where effects of different factors on variability of litter weight at weaning were corrected for age of piglets (equivalent to duration of lactation) and number of weaned piglets, in order to, as stated by authors, obtain more objective results, which is in accordance with our conclusions.

\section{Conclusion}

Carried out investigation of the variability of fertility traits demonstrated that different paragenetic factors influence their expression. Achieved fertility of observed female breeding animals of Swedish Landrace breed was below the genetic potential of this breed.

Statistically highly significant differences between the groups of half- 
sisters with same sire were determined for all litter size and weight traits in first three parities (except W-E and E-C).

All fertility traits varied $(\mathrm{P}<0.01)$ depending on the order of farrowing.

Year and season caused no differences in achieved fertility of sows, except for weight of litter at weaning (LWW) in first two and first three parities.

Number of still born piglets (NSB) in litter as well as litter size at weaning $(\mathrm{NW})$ depended on $(\mathrm{P}<0.01)$ the factor whether for conception of sows boars of Swedish Landrace or another breed were used.

Age of female animals at first farrowing (AFF) expressed linear effect $(\mathrm{P}<0.01)$ on litter size at birth $(\mathrm{NBA}$ and $\mathrm{TNB})$, whereas variation of remaining traits occurred independently from this parameter.

Litter size and weight at weaning (NW and LWW) were under linear regression effect of lactation duration (L) and number of raised (CLS) or weaned (NW) piglets in litter. These factors mostly influenced variation of mentioned traits, which further induced the need to correct their expression to average values of mentioned factors when determining genetic variability.

\title{
FENOTIPSKA VARIJABILNOST OSOBINA PLODNOSTI ČISTORASNIH KRMAČA U PRVA TRI PRAŠENJA
}

\author{
D. Radojković, M. Petrović, M. Mijatović, Č. Radović
}

\section{Rezime}

Ispitivanje fenotipske varijabilnosti osobina plodnosti krmača rase švedski landras sprovedeno je u jednom zapatu svinja u Srbiji. Podaci su analizirani primenom različitih modela metoda najmanjih kvadrata (Harvey, 1990), u koje su bili uključeni sledeći fiksni uticaji: otac, godina, sezona, genotip legla i redosled prašenja, kao i regresijski uticaji uzrasta pri prvom prašenju, trajanja laktacije i broja gajene prasadi u leglu. Istraživanjem je bilo obuhvaćeno 926 krmača i njihova 926 prva, 1598 prva dva i 2115 prva tri prašenja.

Prosečna ispoljenost trajanja perioda od zalučenja do estrusa i oplodnje (W-E i W-C), broja živorođene (NBA), ukupnorođene (TNB), mrtvorođene (NSB) i odgajene prasadi (NW) kao i mase legla pri zalučenju (LWW) u 
prvom, prva dva i prva tri prašenja je bila: $9.77,8.51,7.80 ; 23.77,20.98$, $19.49 ; 8.31,8.91,9.19 ; 8.87,9.46,9.78 ; 0.56,0.54,0.51 ; 7.57,8.04,8.24$ i $52.43,58.18,61.10$, respektivno.

Osobine veličine legla su varirale $(\mathrm{P}<0.01)$ pod uticajem oca i redosleda prašenja (prva dva prašenja). Broj mrtvorođene kao i odgajene prasadi $u$ leglu zavisili su od genotipa legla $(\mathrm{P}<0.01)$. Godina i sezona nisu uticale na variranje osobina veličine legla osim na LWW (prva dva i tri prašenja). Uzrast krmača pri prvom prašenju ispoljio je linearan uticaj $(\mathrm{P}<0.01)$ na veličinu njihovih legala pri prašenju (prva tri prašenja). Veličina i masa legla pri zalučenju su bili pod regresijskim uticajem trajanja laktacije, korigovane veličine legla (CLS) ili broja odgajene prasadi (NW).

Ključne reči: krmače, švedski landras, plodnost, varijabilnost

\section{References}

BELIČOVSKI S., VUKOVIĆ V., ANDONOV S. (1997): Influence of genotype, parity and year of farrowing on some reproductive performance of sows. Bulgarian Journal of Agricultural Science, 3, 1, 75-81.

BOESCH M., ROEHE R., LOOFT H., KALM E. (1998): Estimation of the genetic association between purebred and crossbred performance for litter size in pigs. $6^{\text {th }}$ World Congress on Genetics Applied to Livestock Production, Armidale, Australia, 11-16 January, 1998. vol. 23, 595-598.

ESTANY J., SORENSEN D. (1995): Estimation of genetic parameters for litter size in Danish Landrace and Yorkshire pigs. Animal Science, 60, 315324.

HARVEY W.R. (1990): User's guide for LSMLMW and MIXMDL, PC-2 version.

HOANG N.T., SIVARAJASINGAM S. (1998): Comparisons of Yorkshire, Landrace, Duroc and their crosses for litter performance. $6^{\text {th }}$ World Congress on Genetics Applied to Livestock Production, Armidale, Australia, 11-16 January, 1998. vol. 23, 531-534.

KIM M.J., PARK S.D., KIM S.D., HAN S.U., SANG B.C. (1998): Effects of breed and environmental factors on litter size and litter weight of swine. $8^{\text {th }}$ World Conference of Animal Production, Seul, Korea, June 28 - July 4, 1998. Contributed papers, vol. ii, 616-617.

KOSOVAC OLGA, VIDOVIĆ V., PETROVIĆ MILICA (1994): Fenotipski parametri reproduktivnih osobina krmača različitih genotipova u prva dva prašenja. Biotehnologija u stočarstvu, 10, 3-4, 53-56. 
KOSOVAC OLGA, PETROVIĆ MILICA (1995): Uticaj očeva švedskog landrasa na reproduktivne osobine kćeri čistih rasa $i f_{1}$ generacije. Veterinarski glasnik, 49, 5-6, 305-312.

PETROVIĆ MILICA, TEODOROVIĆ M., RADOJKOVIĆ D., KOSOVAC OLGA. (1998a): Determinacija faktora koji utiču na variranje reproduktivnih osobina krmača. Savremena poljoprivreda, 47, 5-6, 121-126.

PETROVIĆ MILICA, VUKOVIC V., RADOJKOVIĆ D., BELIČOVSKI S. (1998b): Estimation of breeding value of boars based on fertility of their daughters. Macedonian Agricultural Review, 45, 1-2, 91-94.

RADOJKOVIĆ D., PETROVIĆ MILICA (2002): Mogućnosti poboljšanja plodnosti svinja primenom tačnije ocene priplodne vrednosti roditelja. XV inovacije u stočarstvu. Biotehnologija u stočarstvu, 18, 5-6, 57-65.

ROEHE R., KENNEDY B.W. (1995): Estimation of genetic parameters for litter size in Canadian Yorkshire and Landrace swine with each parity of farrowing treated as a different trait. Journal of Animal Science, 73, 29592970.

SHOSTAK B., BENKOV B. (1992): "The effect of breed, parity, season and year on the reproductive performance of sows." Genetika i Selektsiya, 25, 5, 429-434.

TEODOROVIĆ M., PETROVIĆ MILICA, TRIVUNOVIĆ SNEŽANA, POPOVIĆ LJILJANA, SREĆKOVIĆ DAGMARA (1995): Reproduktivne osobine krmača švedskog landrasa $u$ prva tri prasenja. Savremena poljoprivreda, 43, 1-2, 35-38.

TEODOROVIĆ M., PETROVIĆ MILICA, RADOVIĆ I., POPOV RADMILA, TRIVUNOVIĆ SNEŽANA (1999): Fenotipsko ispoljavanje, varijabilnost, udeo naslednosti i međuodnosi osobina plodnosti svinja. 1. Starost krmača kod prvog prasenja (I deo). Savremena poljoprivreda, 48, 12, 73-79.

TöLLE VON K. H., THOLEN E., TRAPPMAN W., STORK F.J. (1998): Moglichkeiten der Zuchtwertschatzung fur Reproduktionsmerkmale beim Schwein am Beispiel eines Schweinezuchterverbandes. Zuchtungskunde, 70, 5, 351-361.

YEN H.F., ISLER G.A., HARVEY W.R., IRVIN K.M. (1987): Factors affecting reproductive performance in swine. Journal of Animal Science, 64, 1340-1348.

ZEBROWSKI Z., BLICHARSKI T., OSTROWSKI A. (1991): Uztkowosc rasplodova loch rasy pbz-23 pokrytych knuramy rasy Duroc lub wielkiej bialej polskiej i wartosc tuczna ich potomstva. Roczniki Nauk Rolniczych, Seria b, Zootehnica, 106, 3-4, 39-48. (abstract) 